\begin{tabular}{cc}
\hline Journal of Research in Islamic Education \\
Volume 2, Number 1, June 2020 \\
DOI: https://doi.org/10.25217/jrie.v1i2.993 \\
http://journal.iaimnumetrolampung.ac.id/index.php/jrie \\
\hline
\end{tabular}

\title{
Integrating the Values of Moderate Islam in Social Science Learning: A Qualitaive Study at Islamic Junior High School (MTs) Darul A'mal Metro
}

\author{
Jusmirah \\ Madrasah Tsanawiyah (MTs) Darul A'mal Kota Metro Lampung, Indonesia \\ ( Ibu.jusmirah1987@gmail.com
}

\begin{abstract}
Article Information:

Received : 2020-6-18

Revised : 2020-6-23

Accepted : 2020-6-23

\section{Keywords:}

Integrating, The Values of Moderate Islam, Social Science Learning

The purpose of the article describing social studies learning integrated with moderate Islamic ideology is able to ward off religious ideology (thiology) with characteristics: First, escapist radicalism, trying to release worldly life, ascetic life, freeing themselves from worldly pleasures that are considered poisonous and virtual. Second, theological-idiological radicalism, building an exclusive community, as an anti-group identity the surrounding world that is considered to be like the devil's world must be eradicated. The method of data collection is done by observation and interviews obtained from the staff of 8 MTs educators and 4 students who were analyzed using a quantitative approach. From the stages of the research conducted found several main components in counteracting radical ideology through the integration of social studies learning namely 1). Formulating competency achievements, 2). Formulating the description of the subjects in the RPP based on moderate Islamic values, 3). Implementing learning by instilling an attitude (tassamuh, tawasud, tawazun). Conclusion of the changes made, first through the achievement of competence, secondly formulating a description of each social studies subject integrated with the Islamic concept of Rahmatan lil 'alamin , thirdly learning strategies are integrated with the concept of wasaton, fourth in evaluating the portion of the attitude assessment component. The resulting impact: 1). Islam rahmatan lil 'alamin , mapu build tolerance, harmony and peace without violence. 2). Islam will continue to synergize with culture, in search of the relevance of universal values of religion in responding to life's problems.
\end{abstract}

\section{INTRODUCTION}

Changes in various social phenomena, Islam began to be interesting to become a study in the process of cultural change (Budiarti, 2015). The inclusion of historical instruments, theology, philosophy, sociology, and the psychology of religion, as a new source of inspiration in translating Islam (Sutrisno, 2019), more or less has various implications, how to read and interpret Islam according to the context and paradigm setting adopted by each each of his followers(Priatmoko, 2018). Fundamental Islam, Liberal Islam, Radical Islam, is an Islamic phenomenon, how this religion intends to respond to the development of society, the rapid development of science and the development of the industrial world today [1], especially 
Integrating the Values of Moderate Islam in Social Science Learning... Jusmirah

now that it has reached the industrial era 5.0. The forms of responses that appear are often in conflict with each other, this is due to differences in conceptualization, argumentation base, paradigm, orientation and a growing spirit. However, each remains on the commitment and a line of struggle, how Islam can be accepted in the context of cultural change in Indonesian society.

Reactualization of religious discourse is one of the 'thought movements' of various phenomena of religious communities in adapting and responding to changing times. This occurs due to the nature of religion itself as a living social phenomenon, as well as politics, economics, psychology, anthropology and such, always wanting to adjust its existence according to the time and conditions that surround it(Rapik, 2014). Religion is thus a universal phenomenon, is the most important ingredient in human life. Islam as one of the great traditions of world religion and even Islam in Indonesia as the majority religion is able to side with other religions such as: Christianity, Catholicism, Hinduism, Buddhism and Koghucu, Islam is a "living organism", which develops according to the pulse of human development. One of the characteristics of Islam according to Clifford Geertz is that it is not an autonomous entity, Islam always appears in its diverse face in the direction of the sociocultural diversity in which Islam is located. Islam is not a dead monument that is idolized, but it needs to be kept alive, read, interpreted and (Subandi, 2017)contextualized. Islam is thus not only a ritual system involving beliefs and aqeedah taken for granted, but broader than that it is a cultural system, HR. Gibb, who has an important connection to every problem of human life. Islam from time to time will continue to be associated with every cultural phenomenon, in search of the relevance of universal values of religion to answer the problem of humanity.

Problems of social life that occur in the modern era often occur at a crossroads, a fact in 2002, Referring to the research report of the United Nations Support Facility for Indonesian Recovery (UNSFIR) in 2002, cases of violence and riots increased sharply. both in terms of the quantity of cases and the quality of the intensity of cases that occur in various dimensions, there are political, socio-economic, religious nuances. The Indonesian nation is currently facing a multidemential crisis. This multidemential crisis is actually rooted in the decline of nationalism, the rise of radicalism and terrorist acts of terror bombings occurred in three greja in Sidoharjo, East Java, and several Polres in Java and Sumatra, and the incident of hostage taking and the murder in Mako Brimob, Jakarta, this case shows a decline in moral quality and the emergence of radical ideology. some of the Indonesian people (Asrori, 2015). The radical ideology began to wane in the campus world. It was released from the State Intelligence Agency (BIN) in 2018, there were 7 State Higher Perguan (PTUN) in Indonesia, especially in 
Integrating the Values of Moderate Islam in Social Science Learning... Jusmirah

the medical and exact faculties already exposed to radical ideas (purwnto day BIN spokesperson). Imam Majid Istiqlal of Jakarta Nasaruddin Umar stated that 40 mosques of the ministry of religion had been exposed to religious radicalism, Jumadi azdra An expert from UIN Syarif Hidayatullah stated that State Islamic College (PTKIN) students were 39\% exposed to radical ideology(Abidin, 2010) .

The emergence of radical ideologies that underlie the rise of social dynamics such as 1). Problem Mythology of Religion, 2). Problem interpretation and symbolic diversity, 3). Problems of injustice and social inequality. Problem and social conditions every life is included in the discussion of social studies on material social inequality. One understanding of radical ideology groups states that this life is the grace of God Almighty, then there must be no difference in life, there is no oppression in life and no one is the most powerful, because the highest strength is the power of God. Religious radicalism began to become a major issue when bombs shook human peace. Cases of the Bali bombings, the Christmas bombings, September, KFC (Kentucky Fried Chicken) and the many violent and corrupt places committed by radical Islamic warriors and mass organizations, such as the Indonesian Muslim Brotherhood, Indonesian Muslim Defenders Front, Islamic Defenders Front, Indonesian Majlis Mujahidin, Laskar Jihad Ablussunah Wal Jamaah, Hezbollah, Jundullah and similar mass organizations that have similar characteristics voice loud voices of jihad against violence.

When the harmony of mankind begins to be disturbed in discomfort, there is of course an effort to restore the conditions of harmony, comfort, peace, respect and tolerance, events like this can be done through the process of inculcating moderate Islamic values (Aswaja) instilled through learning and instilling attitudes and behaviors in life, these attitudes in the educational process begin through an integrated teaching and education process in Madrasas.

\section{METHOD}

Type of research used in this study is qualitative research to describe the findings in the field by interview, observation and documentation data collection methods. 10 informants consisting of 8 educators and 4 students with the validity of data engineering techniques, by displaying data, tabulating data and drawing conclusions.

\section{FINDINGS AND DISCUSSION}

\section{Social Studies Learning Integrated Moderate Islam}

Integrating in the implementation of learning about moderate Islam (Rahmatan lil 'alamin), this step can be taken in several ways namely. 1). Integrate with the domain of competency achievement in the attitude of tolerance, please help, uphold the good without 
Integrating the Values of Moderate Islam in Social Science Learning... Jusmirah

doing violence(Fuad, 2018).2). Establish curriculum material into sharing the eyes of religious institutions, namely on the understanding of tawasud, tasamuh, tawazun and amar ma'ruf nahi munkar,(Rasyid, 2016)3). Developing learning that produces more soft skills than Hard skill, (Asmani, 2017), 4. Having a culture of implementing values of tolerance, respect for diversity and humanity(Mahfud, 2010).

Islam is a religion of peace and supports the peace of mankind, prioritizing harmony and non-violence and intolerant attitudes that will tarnish the face of Islam that is Rahmatan lil 'alamin.Islam in Indonesia is Islam in Indonesia that is adaptive, inclusive and tolerant. However, this condition is diametrically opposed, if you look at Indonesia lately, where violence has escalated. This event can be seen for example from the many cases that ended in acts of violence; Bali bombing cases, mass violence in Banjarmasin, Ambon, Maluku, Situbondo, Tasikmalaya and so on. Cases of violence with a religious background can lead to new views about Indonesian Islam; intolerance and violence (Asghar, 2016). Edward Said, Professor from Columbia University wrote: "For the right group Islam represents barbarianism, for the left group is a medieval theocracy, for the middle group, a kind of exoterism which is disliked. But in all groups there is agreement that although the Islamic world is well known, but not so recognized there, regarding issues of violence and the meaning of violence, Islam is usually seen to be very oriented towards violence. "To avoid the assumptions and perceptions of Islam in Indonesia as haunting ghosts in the republic of fear, borrowing the term Samir al-Kholil, identifying the term violence and coercion, it is important to re-consider the struggle without violence, to reconsider the prophetic value of Islam that respects life

In order to avoid the threat of violence, that religion in principle has a link between teachings and religion that instructs humans not to interfere with life to avoid violence $\mathrm{p}$ there are basically manifestations of behavior that values life. Islam in particular highly values and protects life (Margaretha \& Irianto, 2011). If someone saves one soul, it is as if saving all humanity (Asmani, 2017). But on the other hand, whoever kills a person for no apparent reason seems to kill a whole person.

Some writings relating to this issue include: "Crescent Anti-Violence: Eight Theses on Actions Against Violence of Muslims" (Chaiwat Satha Anand, director of the Peace Information Center, University of Bangkok). There is an "Islam Against Violence and Global Transformation" (Mamoon al-Rasyeed, founder of CRESCENT, Comprehensive Rural Educational, Social, Cultural and Economic Center, Dhaka Bangladesh). Also, "Islam Against Violence and Women" met(Kholidah Moh. Sholeeh, Professor of Physics at the Malaysian National University). Also 
Integrating the Values of Moderate Islam in Social Science Learning... Jusmirah

released, "Islam Anti Violence and Interfaith Relations" (M. Mazzahim Mohideen, Director of the Marga Colombo Srilanka Institute), and "Islam Anti Violence and Global Transformation (Abdurrahman Wahid, Indonesia). Islam from time to time will continue to be connected with each cultural phenomenon, for the relevance of the universal values of religion to answer problems of humanity(Priyambodo,2017).

\section{Democracy, Tolerance and The Diversity in Islamic Values}

Democracy which bases itself on the principles of liberty, equality, and sovereignty of the people, basically in line with the spirit of value taught by Islam, if democracy as an idea that is based on the principles of freedom, equality, and human sovereignty to determine matters relating to public affairs, then fundamentally in line with Islamic teachings, this refers to the principles or values values that become a reference for the struggle of Islam(Aji, 2015) : namely (1). Equality (al-Musyawah / Equality), (2). Independence or freedom based on moral and legal responsibility (al-Hurriyah / Freedom), (3). Brotherhood (alUkhuwah / Brotherhood), (4). Justice (al- 'Is / Justice), (5). Deliberation / al Shura. Deliberation is the value of democracy in the teachings of Islam. Islam does not use the term democracy, but its spirit is not anti-democratic. Deliberation is an Islamic order that will be able to adhere to social organizations, because of the growth of a sense of belonging (Sense of Belonging) and a sense of responsibility (Sense of Responsibility).As-Sha'ili.

The spirit of human rights, tolerance and humanity as part of the promotion of democratic values, is also found in the sources of Islamic teachings. These include those from the Islamic teachings on the rights to which human / community / state fulfillment must be sought which is often called al-Kulliyat al-Khamsah, in the form of general provisions which are at the same time a standard for basic human rights (Maryani \& Syamsudin, 2009). Provisions regarding the preservation of personal safety protection (body and soul, honor, Hifd an-Nafs) indicate the existence of the right to life, which means that humans have the right not to be killed, injured, expelled, tortured, tarnished by their good name, and so on. Furthermore, the stipulations on the preservation of the protection of the mind (Hidf al-'Aql) indicate the existence of free thinking, the right to know and the right to gain knowledge, the right to free oneself from ignorance (Usman, 2015).

The right to express an opinion, the right to be consulted (deliberation) all of which starts from the safety of the mind itself because it is maintained its sanity, not crazy or tsafib. Provisions on the preservation of the protection of the safety of the people (Hifd an Nasl), heredity, indicate the existence of married life, fatherhood rights, maternal rights, children's rights, family's rights to family and so on. Provisions on the requirement for the protection of 
Integrating the Values of Moderate Islam in Social Science Learning... Jusmirah

property rights (Hifd al Mal) indicate the recognition of ownership rights, property rights, property rights, business rights, trade rights, and so on. The key to everything is the stipulation of the preservation of the protection of religious adherents who are believed and worship according to their beliefs (Hifd ad-Din), signifying the recognition of religious rights, maintaining their beliefs and carrying out teachings in accordance with their choices and attitudes in life. From these provisions, it is clear, that Islam have teachings that contain values that are in line with democracy. If we open the holy book which is the reference of Muslims, pluralism is the initial spirit of human early creation; different tribes and nations (QS 49: 13), different languages and skin colors (QS 30: 22), are a reflection of God's will to educate humans to understand diversity. From this principle was born the command to complement each other, and complement each other and help one another.

Although the Qur'an is rich in values that are in line with democracy, Islamic thought views democratic discourse in three main streams(Iryani, 2017). First, democracy is made by human reason, not from God, which does not rely on revelation from heaven and has no relationship with any religion. Democracy was born as a result of the separation of religion from state life. Democracy is based on sovereignty in the hands of the people and the people as a source of power(Nur, 2016). Voxpopuli voxdei, the voice of the people is the voice of God, is considered excessive, which in fundamentalism figures such as the Muslim Brotherhood (Al-Banna and Sayyid Qutb) and Jama'at Islamiyah Al-Maududi, reject this concept. According to him, for reasons of democracy, the majority vote legalized gambling, prostitution and free sex, even though the decision-making process was based on deliberation and collective agreement.

Second, human autonomy will be realized prima and democracy will grow when God and religion are eliminated from human reasoning and action. As long as humans still invite God's intervention to regulate their lives, as long as humans kill their own creativity

Third, opinions that try to combine the two concepts. True sovereignty is in the hands of God, while people's authority is a sacred trust that must be within the bounds of God's will. In other words, the concept of democracy is accepted, and at the same time does not deny the sovereignty of God. Prominent figures and thinkers, for example, Moh. Natsir, Ismail Sunny, and Munawir Sadzali (Ghoffir, 2002).

In the history of Islamic politics, democracy lacks its proper place, although deliberation is also not completely abandoned. The Islamic political system does not set a standard political system, because what each leader faces is different. Conflict and contradiction in seizing power, which is not in line with democratic principles, is a historical 
Integrating the Values of Moderate Islam in Social Science Learning... Jusmirah

problem in Islamic leadership. Ali and Muawiyah built the caliphate on the sharpness of the sword and the sharpness of the spear. Likewise the Caliphate afterwards. Yazid ibn Muawiyah, because of his love for power he permitted the noble blood of Husayn ibn Fatimah bint Rasulullah, and justified the Kaaba to be destroyed for the sake of the concession of his authority. Abu Al-Abbas Al-Saffah drained hundreds of Muslims' blood to seize power. After that, the Abassiyah Dynasty was involved in killing and rebellion in decisions related to power. In similar cases of other caliphs such as Tubektigin from Ghazwani, Saleh Al-Ayyubi fought his brother, Al-'Adil ibn Al Kamil, and the Mamluk Daula was not free from killing to kill. A similar picture is found in the Ottoman Empire in Turkey. Politically, Islam is still far from democratic principles that value differences of opinion, tolerance, human rights and respect the rights of the people.

However, the role of religion in the process of democratization remains relevant. Religion can see its role in the process of democratization, when its adherents' understanding of the values and teachings of their religion, the attitude of the concepts of equality, independence, brotherhood, justice and deliberation, are placed as facilities for the development of democracy(Iryani, 2017). To achieve this goal people need empowerment, citizens who are aware of individual rights and their independence. Islam is a religion of democracy, said Gus Dur, because religion has laws so that all people are treated equally, have the principle of deliberation (shura) to unite the wishes and desires of the community. Islam holds the view that it always wants to improve the lives of the people (Mashalih ar Raiyyah) and the principles of justice that are championed(Priyambodo, 2017).

If democracy and religion both appreciate independence (al-Hurriyab) especially independence to determine and express freedom to choose religious choices (ffifd ad-Din) is there a space that allows people, groups, countries to harass, oppress, dissolve a religious group certain minorities(Ramadan, 2019).

To instill anti-violence Islam and moderate Islam in higher education in counteracting radical ideology, through the implementation of learning in the learning process in maadrasah, this needs to be built as a whole (Tolal Management)(Ramadhan, 2019), so it will be able to solve life's problems in society, because the madrasa will print intellectual human resources that are equipped with soft skills and hart skills. For that it needs to process through the following stages of the cycle (Subandi, 2018): 
Integrating the Values of Moderate Islam in Social Science Learning... Jusmirah

Figure.1. The moderate Islamic cycle is integrated in social studies learning.

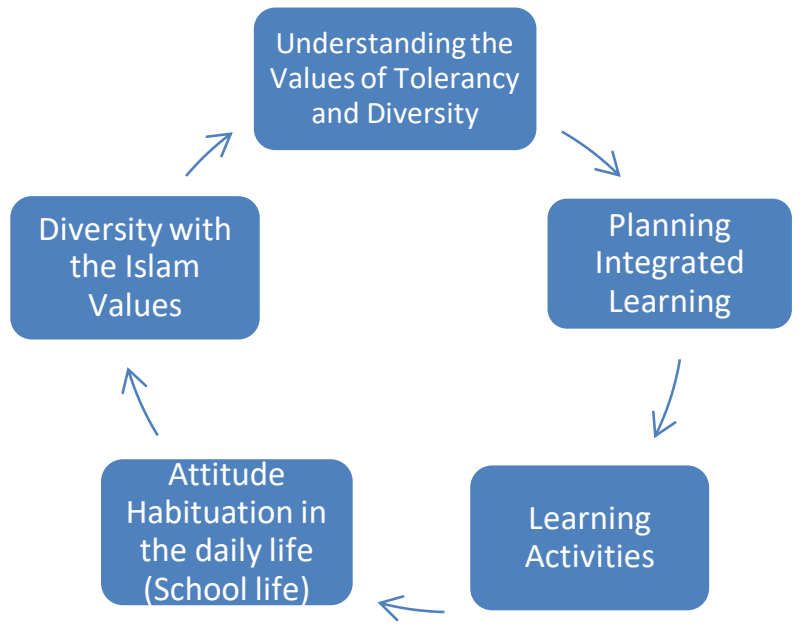

In the implementation of social studies learning in Madrasas through the stage first, educators and students to thoroughly understand moderate Islam (Priatmoko, 2018)with thesocial studies second intending to instill the values of tolerance, diversity and diversity, the third, in learning able to carry out tolerance, Islam without violence, fourth, do habituation to respect the difference between fellow humans to build togetherness. Fifth, ableliving together without violence, Islam that is rabmatan lil 'alamin to build a culture ofin the beloved country of Indonesia is thus able to build cultural diversity and diversity in Madrasas and build Islamic ukuwah and ukuwah wathoniah(Arpannudin, 2016).

\section{CONCLUSION}

Social studies learning is integrated with moderate Islam (wasathoconcepts) by incorporating curriculum planningthrough stages, 1). formulate attainment achievement attitudes that can lead to tolerance, harmony, teposeliro) with the strength of local potential (local wisdom) applying Islamic values rahmatan lil 'alamin (tawassud, tasamub, tawazun, i'tidal ). 2). The process of implementing learning that is responded to, through discussion, exchange of opinions andproblem-based learning, students and educators are able to analyze God's creation with regularity, perfection created by God and the students' analysis of sunatullah in life. 3). The end of the learning process is assessed by the integrated social studies learning to apply attitudes (soft skills) which are more portion (tolerance, diversity and love of the homeland). As the impact of integrated learning, it is able to build people to be diverse but appropriate in harmony and peace without violence, which is reflected in competence with Islam is a phenomenon of social life, in search of the relevance of universal values of religion to answer the problems of social life 
Integrating the Values of Moderate Islam in Social Science Learning...

Jusmirah

\section{REFERENCES}

Abidin, Z. (2010). Gerakan politik Hįbut Tahrir Indonesia (HTI) sebagai organisasi Islam ekstra parlementer di Indonesia pasca reformasi [PhD Thesis]. IAIN Walisongo.

Aji, A. M. (2015). Hak dan Kewajiban Asasi Manusia Dalam Perspektif Islam. SALAM: Jurnal Sosial dan Budaya Syar-i, 2(2).

Arpannudin, I. (2016). Implementasi nilai sosial ukhuwah islamiah di pondok pesantren. Humanika, 16(1), 1-14.

Asghar, A. (2016). Gerakan Terorisme Tahun 2015: Pola Serangan, Jumlah Korban dan Wajah Baru Global Jihad. Jurnal Keamanan Nasional, 2(1), 1-18.

Asmani, J. M. (2017). Rekonstruksi Teologi Radikalisme di Indonesia, Menuju Islam Rahmatan Lil Alamin. Wahana Akademika: Jurnal Studi Islam dan Sosial, 4(1), 3-18.

Asrori, A. (2015). Radikalisme di Indonesia: Antara historisitas dan antropisitas. Kalam, 9(2), $253-268$.

Budiarti, Y. (2015). Pengembangan kemampuan kreativitas dalam pembelajaran IPS. Jurnal Pendidikan Ekonomi Um Metro, 3(1).

Fuad, A. J. (2018). Pembelajaran Toleransi: Upaya Guru Pendidikan Agama Islam Dalam Menangkal Paham Radikal Di Sekolah. Proceedings of Annual Conference for Muslim Scholars, 561571.

Iryani, E. (2017). Hukum Islam, Demokrasi dan Hak Asasi Manusia. Jurnal Ilmiah Universitas Batanghari Jambi, 17(2), 24-31.

Mahfud, M. D. (2010). Gus Dur; Islam, Politik dan Kebangsaan (Bonus VCD Munajat \& Shalawat bersama Gus Dur, Mahfud MD dan Soraya). LKIS PELANGI AKSARA.

Margaretha, R., \& Irianto, S. (2011). Piil Pesenggiri: Modal Budaya dan Strategi Identitas Ulun Lampung. Makara Hubs-Asia.

Maryani, E., \& Syamsudin, H. (2009). Pengembangan Program Pembelajaran IPS untuk meningkatkan kompetensi Keterampilan sosial. Jurnal Penelitian, 9(1).

Nur, A. (2016). Konsep Wasathiyah Dalam Al-Quran;(Studi Komparatif Antara Tafsir AlTahrîr Wa At-Tanwîr Dan Aisar At-Tafâsîr). Jurnal An-Nur, 4(2).

Priatmoko, S. (2018). Pengarusutamaan Nilai-Nilai Islam Moderat Melalui Revitalisasi Pancasila dalam Pendidikan Islam. Proceedings of Annual Conference for Muslim Scholars, 731-741.

Priyambodo, A. B. (2017). Implementasi Pendidikan Karakter Semangat Kebangsaan dan Cinta Tanah Air pada Sekolah Berlatar Belakang Islam di Kota Pasuruan. Jurnal Sains Psikologi, 6(1). 
Integrating the Values of Moderate Islam in Social Science Learning... Jusmirah

Ramadhan, M. R. (2019). Integrasi Nilai Islam Moderat dalam Pendidikan Islam untuk Menguatkan Harmoni Sosial Keagamaan pada Masyarakat Plural. Proceedings of Annual Conference for Muslim Scholars, 3, 701-709.

Rapik, M. (2014). Deradikalisasi Faham Keagamaan Sudut Pandang Islam. INOV ATIF | Jurnal Ilmu Hukum, 7(2).

Rasyid, M. M. (2016). Islam Rahmatan lil Alamin Perspektif KH. Hasyim Muzadi. Episteme: Jurnal Pengembangan Ilmu Keislaman, 11(1), 93-116.

Subandi, S. (2017). Menderadikalisasi Faham Radikal Melalui Pendidikan Multikultur dan Karakter Lokal di Lampung. Fikri: Jurnal Kajian Agama, Sosial dan Budaya, 2(2), 457-484.

Subandi, S. (2018). MANAJEMEN PENDIDIKAN MULTIKULTUR DAN AKTUALISASI ISLAM MODERAT DALAM MEMPERKOKOH NASIONALISME DI INDONESIA. Fikri: Jurnal Kajian Agama, Sosial dan Budaya, 301-312.

Sutrisno, E. (2019). Aktualisasi Moderasi Beragama di Lembaga Pendidikan. Jurnal Bimas Islam, 12(2), 323-348.

Usman, A. M. (2015). ISLAM RAHMAH DAN WASATHIYAH (Paradigma Keberislaman Inklusif, Toleran dan Damai). HUMANIKA, 15(1). 